\title{
Pengembangan Media Boardgame Multikultural AUD Ethnic Enclave Kota Lama melalui Desain Iteratif
}

\author{
Roostrianawahti Soekmono $^{1}$, Erik Armayuda ${ }^{2}$, Duana Fera Risina ${ }^{1}$ \\ Pendidikan Guru Pendidikan Anak Usia Dini, Universitas Trilogi, Indonesia(1) \\ Desain Komunikasi Visual, Universitas Trilogi, Indonesia(2) \\ DOI: $\underline{10.31004 / o b s e s i . v 6 i 3.1904}$
}

\begin{abstract}
Abstrak
Bangsa Indonesia merupakan masyarakat multikultural sehingga sikap toleransi sangat penting. Tema multikultural Ethnic Enclave Kota Lama pada penelitian sebelumnya dapat meningkatkan kesadaran tentang keberagaman Anak Usia Dini (AUD), sebagai pondasi sikap toleransi. Keterbatasan media pembelajaran Pendidikan multikultural, mendorong penelitian ini dilakukan untuk mengembangkan Board Game multikultural Etnic Enclave Kota Lama. Pendekatan penelitiannya menggunakan Penelitian dan Pengembangan dengan tiga langkah yaitu: (1) Penelitian pendahuluan, (2) pengembangan Board Game melalui proses Iteration Design yaitu desain prototipe, tes bermain pada uji coba prototipe 2 anak dan uji coba kelompok kecil pada 8 anak usia 5-6 tahun dan umpan balik berdasarkan intrumen observasi kesadaran tentang keberagaman, (3) tes validasi Board Game menggunakan intrumen validasi elemen dan mekanik boardgame. Hasil penelitian berupa media boardgame multikultural ethnic enclave Kota Lama yang dapat meningkatkan kesadaran tentang keberagaman berupa identifikasi nama dan ciriciri suku serta budaya melalui benda budaya di dalam bangunan di Kota Lama.
\end{abstract}

Kata Kunci: boardgame multikultural; ethnic enclave kota lama; kesadaran keberagaman; desain iteratif.

\begin{abstract}
The Indonesian is a multicultural society so tolerance is very important. The multicultural theme of the Kota Lama Ethnic Enclave in previous srudies could increase diversity awareness of early childhood which is the foundation of tolerance. But the learning media for multicultural education is still limited, so we develop a multicultural Boardgame of the Kota Lama Ethnic Enclave. The research approach uses Research and Development which consist of three steps, namely: (1) Preliminary research, (2) Boardgame development through the Iteration Design Process, namely Prototype Design, Play test in Prototype trials for 2 children and Small group trials for 8 childrens aged 5-6 years, and feedback based on diversity awareness of observation instruments, (3) Boardgame validation tests, using elements and mechanics boardgame of validation instruments. Research result is Media Boardgame of multicultural ethnic enclave Kota Lama can increase diversity awareness. The child can identification names of ethnic and etnic characteristics as well as cultural identification through culturl objects inside building in Kota Lama.
\end{abstract}

Keywords: multicultural boardgame; ethnic enclave kota lama; diversity awareness; an iteration design

Copyright (c) 2022 Roostrianawahti Soekmono, et al.

$\triangle$ Corresponding author:

Email Address : roostri73@trilogi.ac.id (Jakarta, Indonesia)

Received 1 July 2021, Accepted 17 November 2021, Published 22 November 2021 


\section{PENDAHULUAN}

Anak-anak Indonesia saat ini lebih mengenal budaya global akibatnya budaya lokal dan ke Indonesiaan semakin pudar (Siregar \& Nadiroh, 2017). Hal tersebut mengakibatkan menurunnya rasa cinta budaya dan nasionalisme generasi muda (Yoga Agustin, 2011). Selain itu dapat juga mengancam identitas bangsa (Mubah, 2011). Cara membendung derasnya globalisasi dengan melakukan pelestarian budaya untuk memperkuat eksistensi budaya lokal melalui pengalaman budaya dan pengetahuan budaya (Nahak, 2019). Kenyataannya Indonesia sangat beragam, sehingga menurut Ayzumardi Azra, langkah yang paling strategis adalah melalui Pendidikan Multikultural (Usman, 2018)

Menurut Utari, orangtua dan guru dapat menumbuhkan rasa nasionalisme kepada anak usia dini dengan cara yang menarik melalui permainan tradisional (Utari, 2017). Permainan tradisional dapat menjadi alat transfer nilai yang menyandingkan budaya lokal dengan budaya global (Murtiningsih, 2012). Kenyataannya anak milenial lebih menyukai permainan modern dibandingkan permainan tradisional. Permainan menurut Chatifield sebagai bagian dari insting manusia yang menyenangkan dan menjadi bisnis yang paling serius pada abad 21 (Chatfield, 2011). Permainan berkembang sejak lama di hampir semua kebudayaan. Board game yang tertua adalah Backgammon yang berkembang pada kebudayaan islam di kawasan Mesopotamia (Livikacansera, 2012). Jadi Board Game merupakan produk budaya sehingga dapat menjadi media multikultural. Tetapi media multikultural masih terbatas dan saat ini belum ada boardgame multikultural untuk anak usia dini.

Board Game multikultural dapat sebagai alternatif pengganti penggunaan gadget yang berlebihan, karena dapat meningkatkan komunikasi dan interaksi anak dan ini sangat sesuai di masa pandemi (Chiong et al., 2018). Pengembangan desain board game dapat menggunakan proses desain iteratif (An Iterative Design Process) yang terdiri dari desain game, tes bermain dan umpan balik (Akmal \& Coulton, 2019). Saat ini Board Game yang ada lebih dominan mengandung nilai budaya global, pengembangan Board Game multikultural menawarkan unsur budaya lokal-nasional-global, yang dikembangkan dari penelitian sebelumnya, "Model Pendidikan Multikultural melalui Program Bahasa Holistik". Penelitian tersebut mengembangkan identifikasi tema, perencanaan pembelajaran, alat permainan, buku cerita multikultural, dan implementasi pembelajaran multikultural, serta asesmen kesadaran tentang keberagaman (Soekmono, 2017). Salah satu alat permainan berupa prototipe bermain peran mikro akan kembangkan menjadi Board Game multikultural Ethnic Enclave Kota Lama agar mudah di produksi oleh publisher dan digunakan lebih luas. Sehingga peneliti melakukan penelitian Pengembangan Board Game Multikultural Ethnic Enclave Kota Lama melalui Proses Desain Iteratif.

Penelitian ini bertujuan mengidentifikasikan board game multikultural yang akan dikembangkan; Menemukan cara merancang board game multikultural melalui Iterative Approach; Menemukan cara membuat board game multikultural melalui Iterative Approach; dan Mengidentifikasikan kesadaran tentang keberagaman anak setelah bermain dengan board game multikultural.

Board game merupakan permainan yang menggunakan sejumlah benda di atas papan dan saling bertukar berdasarkan aturan tertentu. Board Game ditujukan untuk memberikan pengalaman kolaboratif (Hunsucker, 2016). Board Game menjadi media pendidikan untuk membantu pencapaian tujuan khusus Pendidikan (educational outcomes), mengenalkan sesuatu yang baru dan tidak terlihat menjadi nyata (Rajkovic, Ruzic, \& Ljujic, 2019); board game bilangan yang di mainkan dalam kelompok kecil dapat meningkatkan pengetahuan anak (Ramani, Siegler, \& Hitti, 2012); serta menjadi alat untuk memotivasi, memberdayakan dan mendidik (Treher, 2010). Jadi boardgame merupakan permainan yang menggunakan sejumlah benda di atas papan dengan aturan tertentu yang dapat memberikan pengalaman kolaboratif, membantu pencapaian tujuan khusus Pendidikan, meningkatkan pengetahuan anak dan alat untuk memotivasi dalam Pendidikan. 
Pendidikan multikultural menurut Bank ada dua tujuan: (1) meningkatkan persamaan bidang pendidikan untuk anak-anak dari berbagai suku dan budaya, (2) membantu membangun pengetahuan, sikap dan keterampilan yang diperlukan agar berhasil dalam masyarakat yang beragam. Banks menjabarkan empat dasar pendekatannya, yaitu: (1) The Contributions Approach, (2) The Additional Approach, (3) The Transformation Approach, (4) The Social Action Approach (Banks, 2015). Beberapa ciri pendidikan multikultural menurut Choirul Mahfud yang sejalan dengan pendapat Bank adalah materinya mengajarkan nilai-nilai bangsa, dan kelompok etnis, serta menghargai aspek-aspek perbedaan keberagaman budaya bangsa dan kelompok etnis (Mahfud, 2013). Sehingga dapat disimpulkan bahwa pendidikan multikultural bertujuan untuk membangun pengetahuan, sikap dan keterampilan dalam masyarakat yang beragam/memiliki perbedaan budaya agar memberikan keadilan bagi anak dari berbagai suku dan bangsa dengan menggunakan pendekatan kontribusi, tambahan, transformasi dan aksi sosial.

Board Game multikultural ditujukan untuk membangun identitas kultural sebagai proses pembentukan identitas bangsa. Pada saat bermain board game yang memiliki alur cerita, akan terjadi interaksi melalui aturan main yang sudah di set oleh perancang board game sehingga pemain akan menangkap makna dan nilai-nilai yang terkandung di dalamnya (Lassi A. Liikkanen, 2010). Board game multikultural juga berguna untuk belajar atau menyegarkan kembali pengetahuan anak melalui pendekatan interaktif untuk eksplorasi wilayah suatu negara (Kosa \& Yilmaz, 2017). Jadi boardgame multikultural memiliki nilai-nilai yang dapat digunakan untuk membangun identitas kultural sebagai dasar pembentukan identitas bangsa yang multikultural.

Konsep tema multikultural board game diangkat dari kantong etnis atau Ethnic Enclave Kota Lama Semarang yang menjadi pusat peradaban budaya. Kota Lama dibagi menjadi 4 (empat) kampung yaitu : Kampung Kauman, Kampung Pecinan, Kampung Belanda (Little Netherland), dan Kampung Melayu. Kampung Kauman ditinggali suku Jawa dan etnis Arab, kampung pecinan tempat berkumpulnya etnis cina, kampung Belanda merupakan Kawasan bangsa Belanda da Kampung Melayu berkumpul banyak suku diantaranya suku Jawa, etnis cina, etnis Arab, Suku Melayu dan suku Banjar. Titik sentral Kota Lama adalah jembatan Kali Mberok, Kampung Melayu berada di sebelah utara, Little Netherland berada di sebelah timur, di sebelah barat kampung Kauman dan masyarakat Tionghoa di selatan Kali Mberok yang sekarang menjadi kampung Pecinan (Hendro, 2015).

Konsep tema multikultural Ethnic Enclave Kota Lama dikembangkan dengan proses desain iterative. Desain Iterative merupakan metodologi yang digunakan untuk mengembangkan game yang terdiri dari Desain game, tes bermain (play-testing) dan umpan balik. Desain game berupa penyusun aturan main (mechanics) untuk menfasilitasi interaksi, konsep yang digunakan untuk mengekspresikan ideologi (elements) serta benda yang digunakan untuk menfasilitasi aturan main dan konsep (pieces). Tes bermain berupa ekplorasi dan refleksi desain game. Umpan balik dari temuan proses eksplorasi dan refleksi digunakan untuk memperbaiki prototipe game (Akmal \& Coulton, 2019).

Board game juga bisa dikembangkan dengan proses desain iterative berbasis kelompok diskusi terfokus dan sesi brainstorming. Tahapannya dengan mengembangkan prototipe board game, tes bermain dan umpan balik. Elemen formal prototipe game seperti jumlah pemain, tujuan, aturan permainan, konflik, sumber daya, hasil dan Batasan permainan. Tes bermain dilakukan melalui kelompok diskusi terfokus dan sesi brainstorming. Umpan balik diperoleh dari hasil kelompok diskusi terfokus dan sesi brainstorming (Kosa \& Yilmaz, 2017).

Mekanik merupakan inti dari game, berupa interaksi dan hubungan antara estetika, teknologi dan cerita. Ada beberapa jenis mekanik, yaitu: (1) ruang (space) baik 2 dimensi atau 3 dimensi; (2) waktu (Time) yang sesuai agar boardgame tidak terlalu lama/terlalu cepat; (3) obyek/benda, tanda kelengkapan/atribut, dan status (objects, attributes, and states) berupa karakter, alat-alat yang diperlukan (prop), token, dan papan skor; (4) Aksi (Action) berupa aksi 
dasar dan aksi strategi; (5) Aturan (Rules), berupa aturan operasional, aturan dasar, aturan sikap atau aturan tidak tertulis, aturan tertulis, hukum, aturan resmi, aturan penasehat/rules of strategies, dan aturan rumah; (6) Keterampilan (skill), berupa keterampilan fisik, keterampilan mental, dan keterampilan sosial; (7) Peluang (Chance) yang merupakan kejutan yang memberikan kesenangan (Schell, 2015).

Selain mekanik boardgame memerlukan Keseimbangan Game (Game Balance) diantaranya: (1) Adil (Fairness) yang dapat memberikan sumber dan kekuatan yang sama untuk semua pemain; (2) Tantangan vs. Keberhasilan (Challenge vs. Success), permainan yang terlalu tinggi tantangan membuat pemain cemas/frustasi, sebaliknya kalau terlalu mudah berhasil membuat pemain bosan; (3) Pilihan yang Bermakna (Meaningfull Choice), apabila pilihan sama dengan keinginan maka pemain merasa bebas dan terpenuhi keinginannya; (4) Keterampilan vs. peluang (Skill vs. Chance), game sebaiknya dapat melatih keterampilan pemain, kesempatan mengambil resiko (peluang) dan melakukan strategi; (5) Kepala vs tangan (Heads vs Hands), ada keseimbangan antara tantangan aktivitas fisik dan aktivitas yang melibatkan pikiran/intelektual; (6) Kompetisi vs Kerjasama (Competition vs Cooperation); (7) Pendek vs panjang (Short vs Long), apabila terlalu pendek tidak bermakna dan bila terlalu panjang bosan, (8) Hadiah (Rewards) agar pemain bergairah; (9) Hukuman (Punishment); (10) Kebebasan vs pengalaman dikontrol (Freedom vs Control Experience); (11) simple vs kompleks (Simple vs Complex), simple dan elegan, bukan simple dan membosankan. Game kompleks tetapi sistemnya sederhana bukan terlalu kompleks dan membingungkan; (12) Detail vs Imajinasi (Detail vs Imagination) dimana ada keseimbangan antara detail yang realistik dan detail yang imajinatif (Schell, 2015).

Penelitian di harapkan dapat memberikan manfaat yang sangat penting bagi bangsa Indonesia yang multikultural, yaitu meningkatkan kesadaran tentang keberagaman Anak usia dini yang merupakan pondasi sikap toleransi. Produk ini diharapkan dapat menjadi produk inovasi media pembelajaran multikultural bagi guru PAUD, orangtua, Lembaga PAUD dan penerbit.

\section{METODOLOGI}

Pendekatan dan Metode penelitian yang dipilih adalah Penelitian dan Pengembangan $(\mathrm{R}$ and $\mathrm{D})$ yang menggunakan prosedur dan langkah-langkah penelitian Borg and Gall yang mengadaptasi penggunaan sample prototipe, kelompok kecil dan satu kelas pada desain Instruksional Dick and Carey (Risa Nur Sa'adah, 2020). Sedangkan pengembangan board game multikultural menggunakan Iteration Approach. Gambar 1 adalah tahapan penelitiannya.

Langkah-langkah penelitian terdiri dari penelitian pendahuluan, penelitian pengembangan dan studi evaluasi. Penelitian pendahuluan dilakukan pada tahun pertama melalui studi pustaka tentang data-data yang terkait ethnic enclave Kota Lama dan studi lapangan boardgame anak tentang kota. Penelitian pengembangan di lakukan pada tahun pertama dan kedua, penelitian pada tahun pertama dengan mengembangkan "prototipe awal" (ide) dari boardgame melalui Game Document Designer (GDD) dan Concept Art Design (CAD). Hasilnya di validasi oleh expert judgement pakar multikultural dan pakar media PAUD, kemudian di revisi menjadi "prototipe revisi 1". Selanjutnya dilakukan proses desain iterative dimana "prototipe revisi 1" boardgame di uji coba prototipe dengan melakukan play test pada 2 anak usia 5-6 tahun. Pada saat play test dilakukan observasi dengan instrumen kesadaran tentang keberagaman anak, evaluasi dengan instrumen evaluasi elemen dan mekanik boardgame. Selanjutnya dilakukan analisis data kualitatif sebagai feed back atau bahan revisi boardgame menjadi "prototipe revisi 2". Setelah itu dilakukan lagi proses desain iterative "prototipe revisi 2" boardgame di uji coba kelompok kecil dengan melakukan play test pada 8 anak usia 5-6 tahun. Pada saat play test dilakukan observasi dengan instrumen kesadaran tentang keberagaman anak, evaluasi dengan instrumen evaluasi elemen dan mekanik boardgame. Selanjutnya dilakukan analisis data kualitatif sebagai feed back atau 
bahan revisi boardgame menjadi "prototipe revisi 3". Pada uji coba kelompok kecil dapat dilakukan uji efektivitas model dengan uji Wilcoxon.

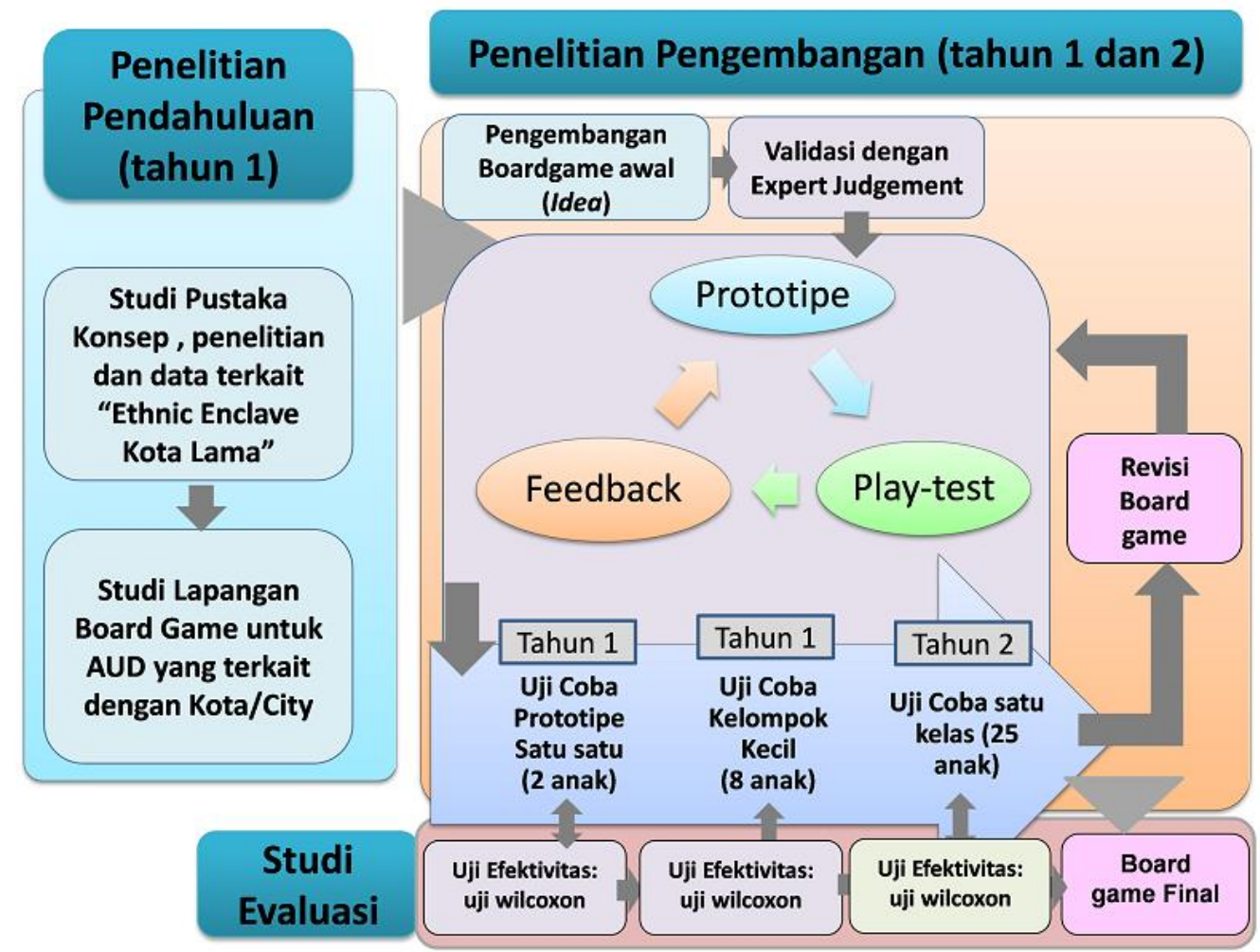

Gambar 1. Langkah-langkah Penelitian Pengembangan Board Game Multikultural "Ethnic Enclave Kota Lama" melalui Iterative Design Process

Lokasi penelitian dilakukan di kota Semarang yang memiliki empat kampung etnis yang sangat beragam (multikultural) sebagai kantong etnis (ethnic enclave) Kota Lama. Uji coba dilakukan pada TK Nasima Semarang karena merupakan lokasi penelitian Dasar sebelumnya. Waktu Penelitian dilakukan pada tahun 2021 s.d. 2022, dan pada tahun 2021 dilakukan dua uji coba yaitu uji coba prototipe pada 2 anak TK B dan uji coba kelompok kecil pada 8 anak TK B (usia 5-6 tahun).

Tehnik analisis data penelitian menggunakan pendekatan kualitatif Inkuiri Naturalistik untuk data kualitatif. Analisis data kualitatif untuk mendapatkan temuantemuan yang dapat digunakan untuk perbaikan media. Prototipe awal boardgame yang merupakan hasil desain content dan elemen serta desain concept art selanjutnya divalidasi elemen dan mekanik oleh expert judgement Pendidikan anak usia dini dan focus grup discussion setelah play test internal oleh tim peneliti. Selanjutnya prototipe awal boardgame direvisi menjadi prototipe revisi 1 boardgame. Kemudian prototipe revisi 1 boardgame di tes dengan play test pada uji coba prototipe ( 2 anak). Pada saat uji coba prototipe dilakukan evaluasi elemen dan mekanik yang menjadi feedback untuk perbaikan prototipe revisi 1 boardgame. Prototipe revisi 1 boardgame diperbaiki lagi menjadi prototipe revisi 2 boardgame. Kemudian prototipe revisi 2 boardgame di tes dengan play test pada uji coba kelompok kecil (8 anak). Pada saat uji coba kelompok kecil dilakukan evaluasi elemen dan mekanik yang menjadi feedback untuk perbaikan prototipe revisi 2 boardgame. Selain play test prototipe revisi 2 boardgame juga di validasi oleh expert judgement boardgame Studio Kumara Bandung sebelum di revisi menjadi prototipe revisi 3 boardgame.

Sedangkan data kuantitatif berupa data interval atau rasio dari hasil observasi kesadran tentang keberagaman anak saat play test dianalisis dengan uji rangking Wilcoxon. Uji rangking Wilcoxon merupakan uji non parametrik untuk data bertipe interval atau rasio. 
Uji Wilcoxon menganalisis hasil-hasil pengamatan yang berpasangan dari dua data apakah berbeda atau tidak. Uji Wilcoxon ini hanya dilakukan pada uji coba kelompok kecil (tahun pertama) dan uji coba satu kelas (tahun kedua).

\section{HASIL DAN PEMBAHASAN}

Tahapan awal penelitian dengan melakukan penelitian pendahuluan berupa studi pustaka dan studi lapangan. Studi pustaka yang dilakukan berupa pengumpulan data tentang keberagaman suku/etnis dan keberagaman budaya di Kota Lama. Data-data keberagaman suku/etnis Kota Lama diperlukan untuk desain content dan elemen kartu suku/etnis, berupa warna kulit dan pakaian adat dari suku/etnis yang ada di Kota Lama yaitu Suku Jawa, Suku Melayu, Suku Banjar, Etnis Cina, Etnis Arab dan Etnis Indo Belanda. Sedangkan studi pustaka data-data keberagaman budaya Kota Lama yang diperlukan untuk desain content dan elemen kartu bangunan serta benda budaya. Keberagaman budaya berupa bentuk bangunan (atap, pintu, jendela) dan macam-macam benda budaya yang ada di 4 kampung Kota Lama yaitu Kampung Kauman, Kampung Belanda, Kampung Pecinan dan Kampung Melayu.

Studi lapangan dilakukan untuk mengeksplorasi boardgame anak usia dini yang bertemakan kota. Boardgame yang bertemakan kota sebagian besar untuk remaja dan dewasa. Beberapa boardgame untuk anak usia dini diantaranya adalah boardgame "Busytown Eye Found it!". Boardgame "Busytown Eye Found it!" memiliki elemen berupa 1 game board, 4 movers, 4 mover bases, 1 spinner, 1 ferry tile, 10 magnifying glass tokens, 6 food tiles, 30 goldbug cards, 1 sand timer, dan instructions. Boardgame ini dimainkan oleh 2 s.d. 4 orang sebagai permainan kooperatif untuk anak pra sekolah pada papan boardgame sepanjang 6 kaki atau $182,88 \mathrm{~cm}$. Elemen dan mechanic boardgame bagus dan beberapa akan diadopsi seperti bentuk papan boardgame, penggunaan kartu, bidak (movers) dan jam pasir. Elemen spinner masih dipertimbangkan karena unsur keberuntungan (lucky) besar, dan peneliti memilih penggunaan kartu agar unsur keberuntungan dikurangi dan digantikan pemecahan masalah.

Tahapan berikutnya adalah penelitian pengembangan yang terdiri dari: (1) pengembangan boardgame awal (idea), (2) Validasi Expert judgement, (3) Proses Desain Iteratif. Pengembangan boardgame awal melalui dua proses yaitu Game Document Designer (GDD) dan Concept Art Design (CAD). GDD dilakukan untuk mendesain Element, Mechanic dan Pieces. Proses GDD untuk konten dari elemen (element) papan boardgame dilaksanakan 2 kali pada bulan Maret 2021, elemen dan jumlah (pieces) kartu bangunan kota lama dilaksanakan 4 kali pada bulan Maret s.d. Mei 2021, elemen dan jumlah kartu suku/etnis dilaksanakan 3 kali pada bulan Maret s.d. April 2021, serta elemen dan jumlah kartu benda budaya dilaksanakan 2 kali pada bulan Maret s.d. April 2021. Proses GDD untuk mekanik (mechanic) dilaksanakan 3 kali pada bulan Maret s.d. Mei 2021.
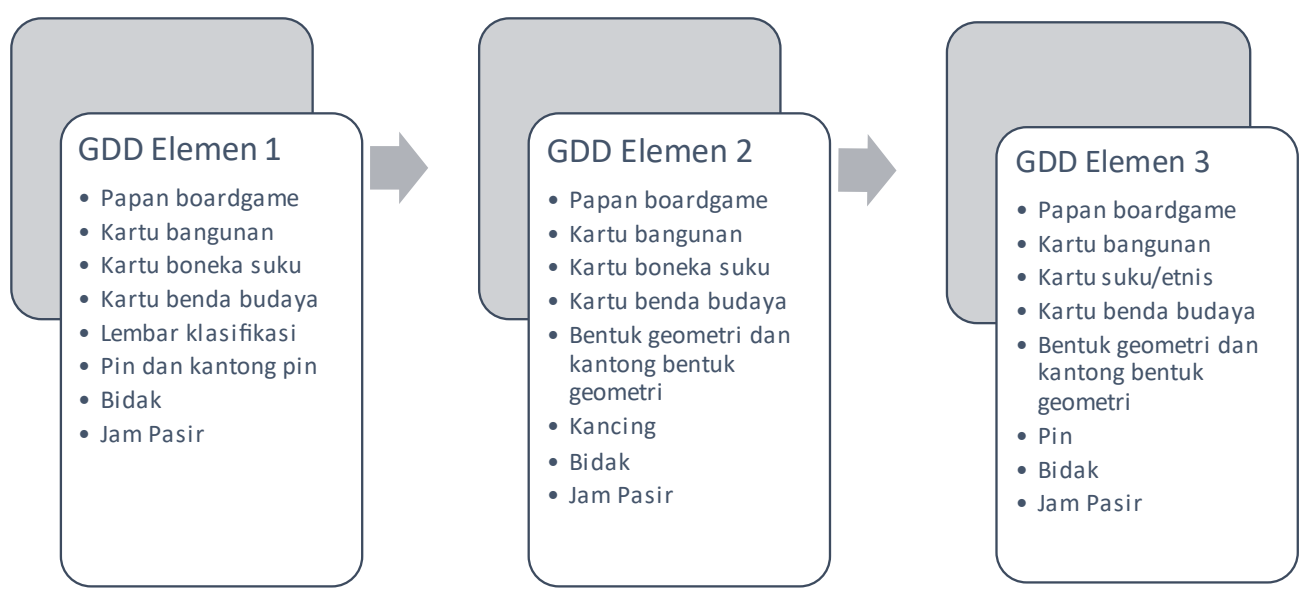

Gambar 2. Hasil GDD Elemen boardgame Multikultural 

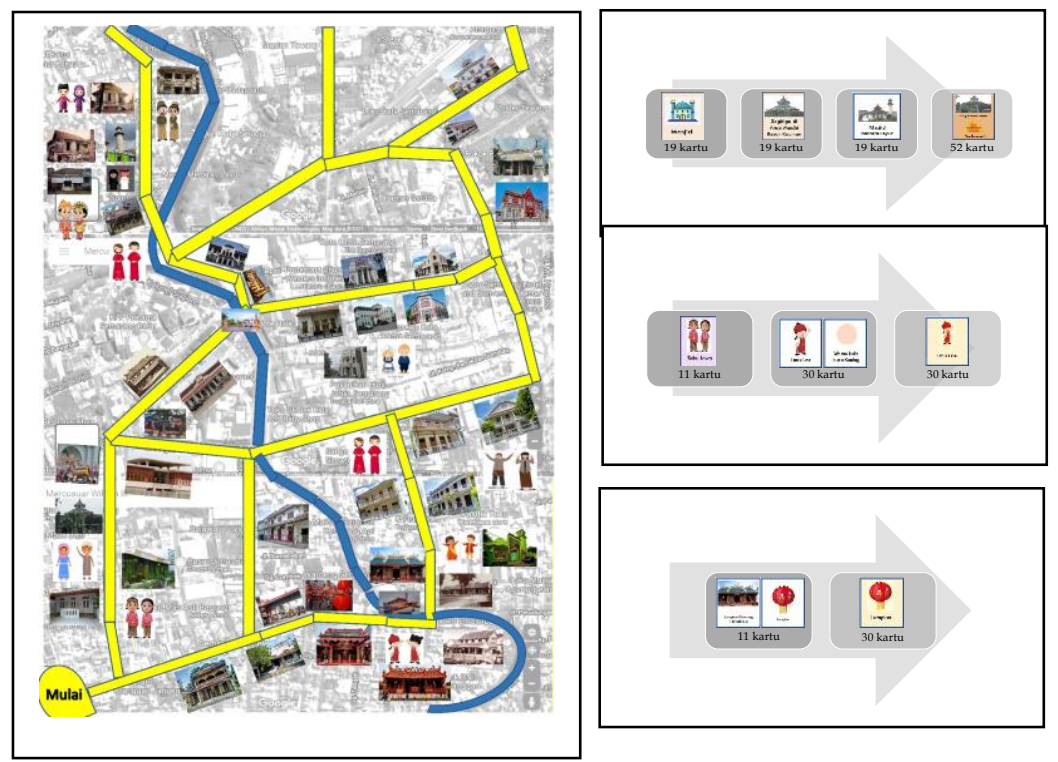

Gambar 3. Hasil Game Document Designer (GDD) Elemen Papan Boardgame, Elemen dan jumlah Kartu Bangunan, Kartu Suku/Etnis serta Kartu Benda Budaya

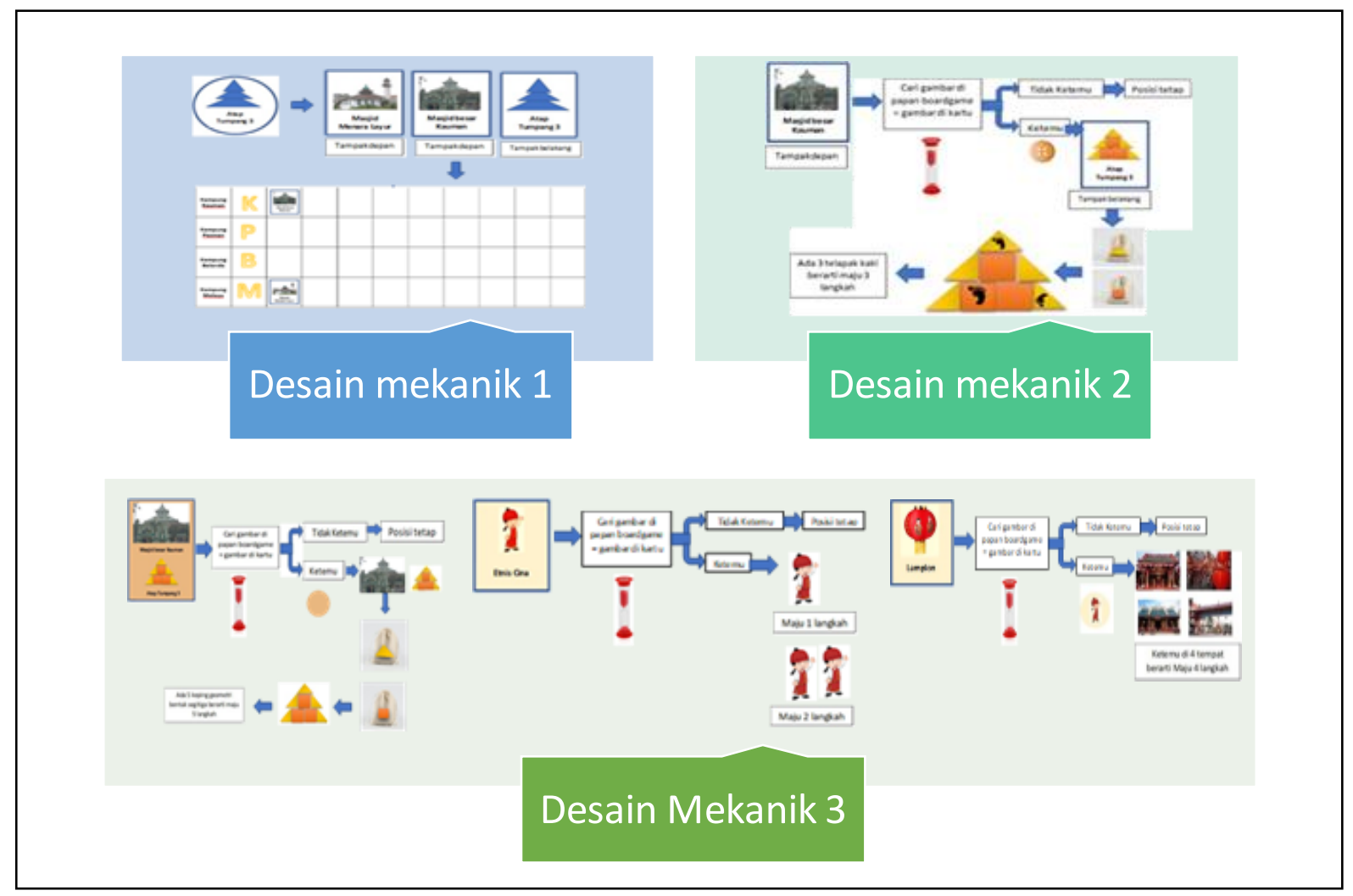

Gambar 4. Hasil Game Document Designer (GDD) Mekanik Boardgame

Setelah proses GDD dilakukan Concept Art Design (CAD) yang meliputi desain logo boardgame, desain papan boardgame, desain kartu bangunan, desain kartu suku/etnis dan desain kartu benda budaya. Desain concept art untuk logo boardgame dikembangkan dari 4 kantong etnis (ethnic enclave) yang berupa 4 kampung etnis di Kota lama yaitu kampung Kauman, kampung Pecinan, kampung Belanda dan kampung Melayu. Papan boardgame di desain berdasarkan konten elemen papan boardgame hasil GDD. Selain itu juga didesain untuk elemen kartu yang terdiri dari kartu suku/etnis (36 kartu/pieces), kartu Kota Lama (33 
kartu/pieces), dan kartu benda budaya (26 kartu/pieces). Desain gambar dapat dilihat pada gambar 5 dan 6.

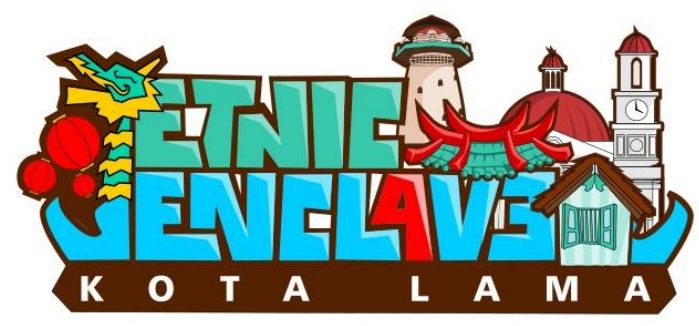

Gambar 5. Logo Boardgame Multikultural Ethnic Enclave Kota Lama
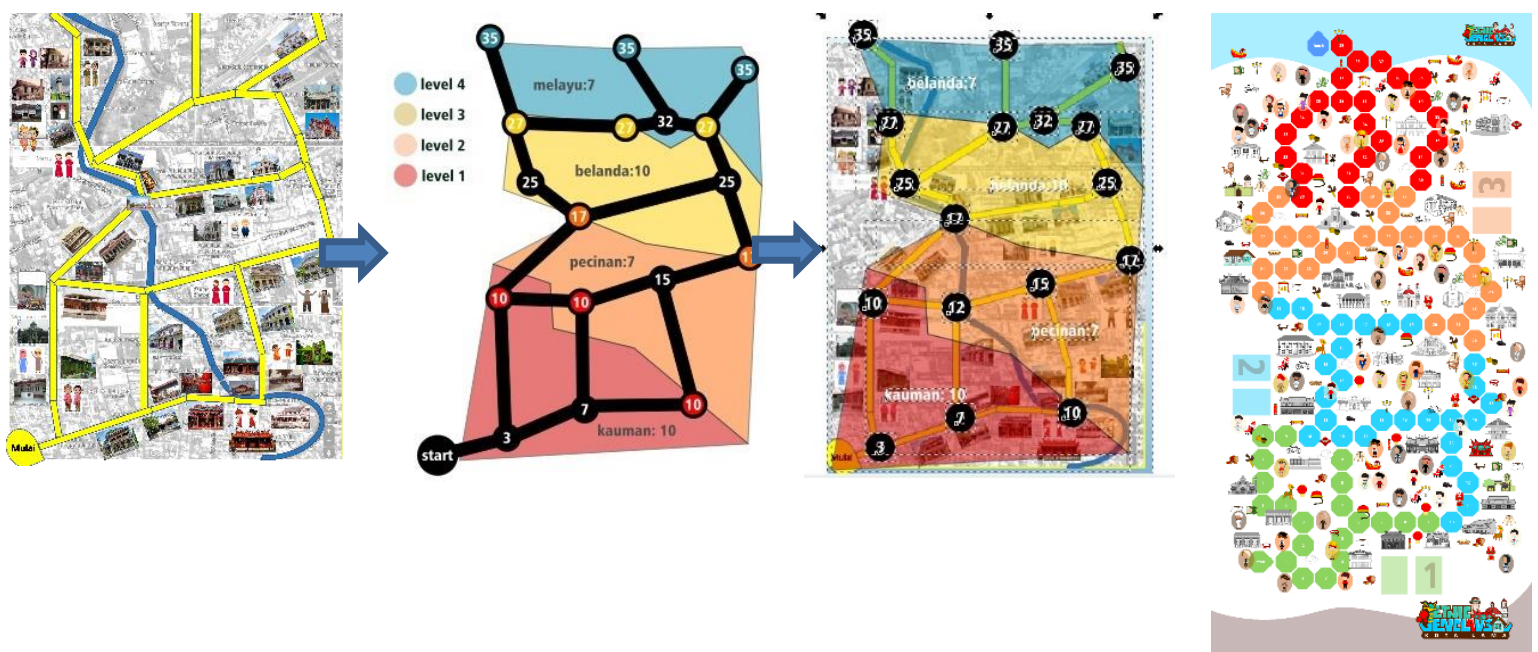

Gambar 6. Hasil CAD 1 berupa "prototipe awal" Elemen Papan boardgame multikultural
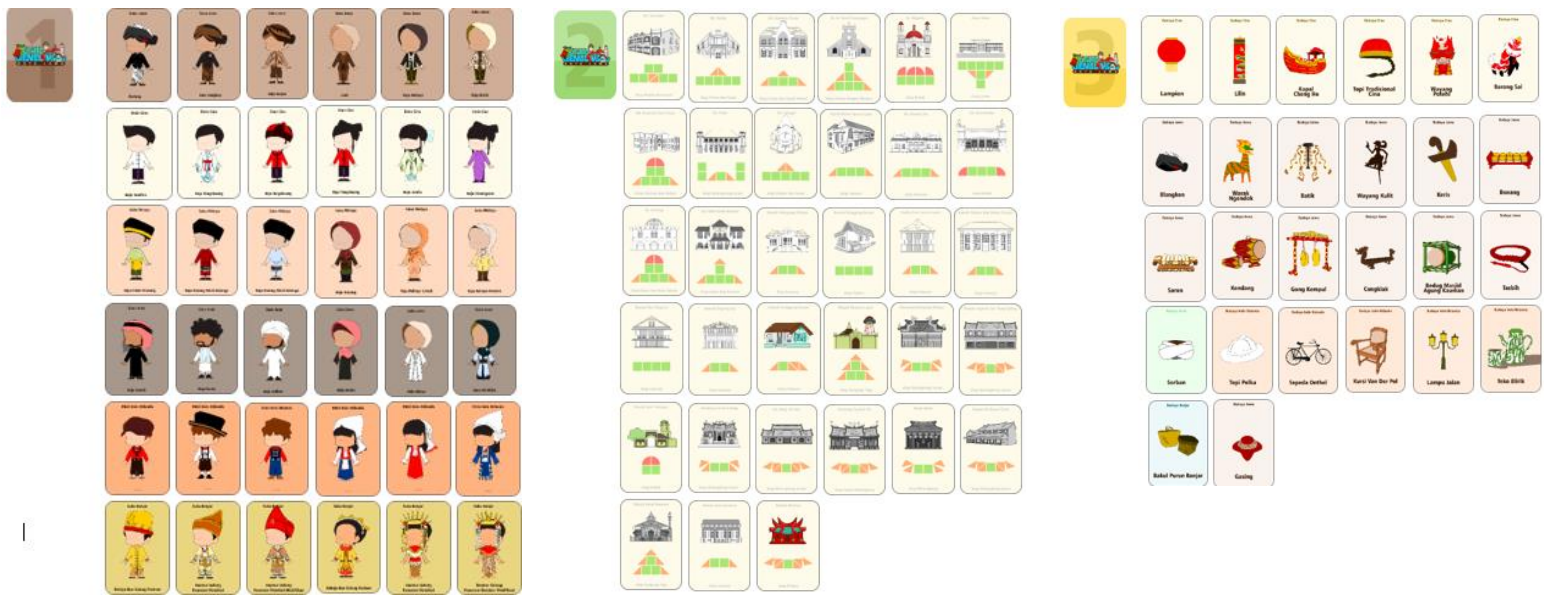

Gambar 7. Hasil Concept Art Design (CAD) 1 berupa "prototipe awal" Elemen kartu suku/ etnis (30 kartu), kartu bangunan (33 kartu) dan kartu benda budaya (26 kartu)

Hasil CAD 1 tersebut berupa "prototipe awal" boardgame multikultural ethnic enclave Kota Lama selanjutnya di validasi expert judgement oleh pakar Pendidikan Anak Usia Dini dan pakar Multikultural, play test internal oleh mahasiswa, dan Peer Evaluation. Hasil validasi, play test internal dan Peer Evaluation selanjutnya di analisis serta menjadi bahan Focus Grup Discussion 1 (FGD 1) dan revisi "prototipe awal" boardgame multikultural sebagai persiapan Uji Coba Prototipe. Tabel 1 dan 2 adalah hasil rekapitulasi revisi yang merupakan bahan FGD 1 dan revisi "prototipe awal" boardgame multikultural. 
Tabel 1. Hasil Validasi Expert Judgement, Play test internal dan Peer Evaluation pada elemen boardgame

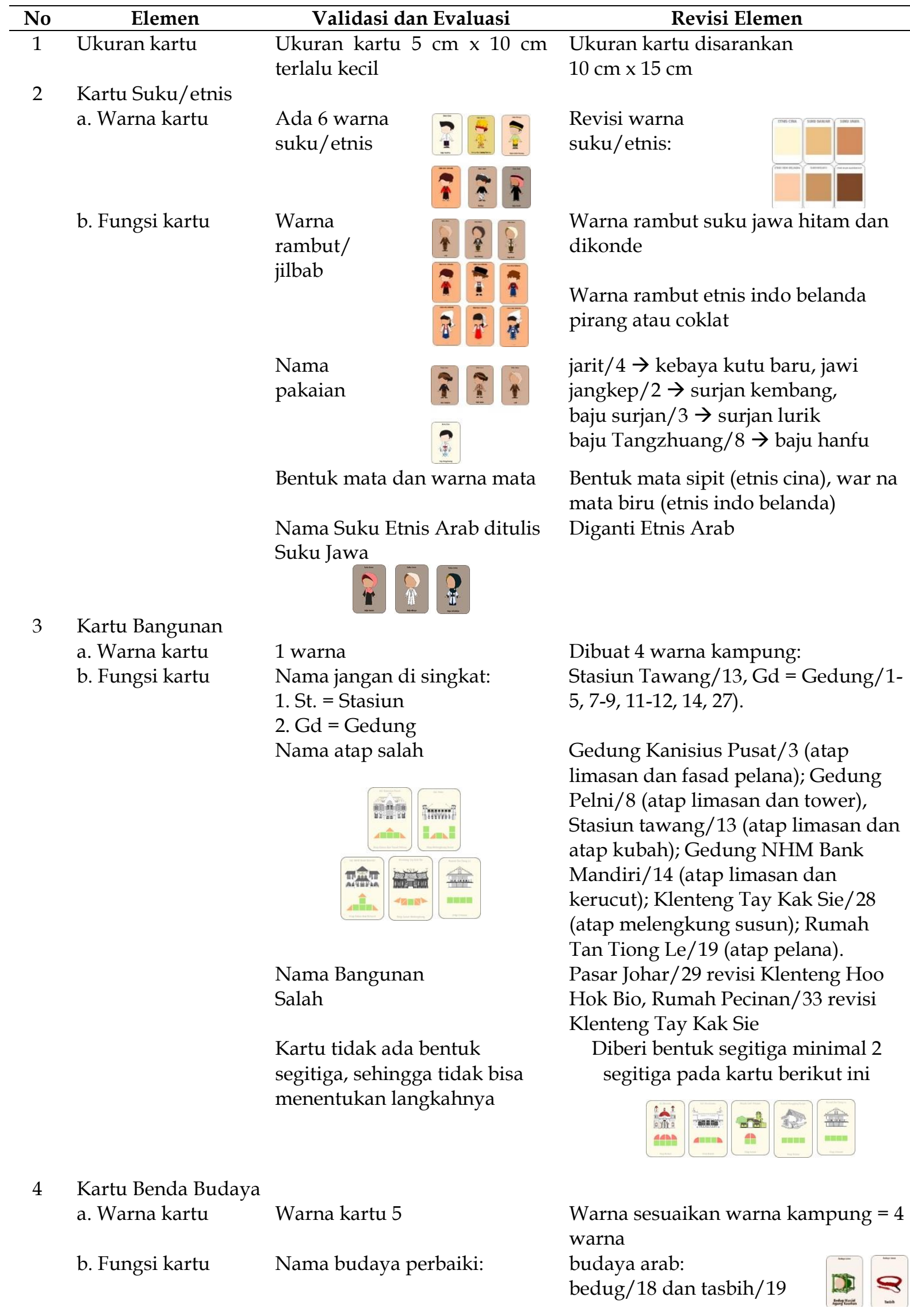



DOI: 10.31004/obsesi.v6i3.1904

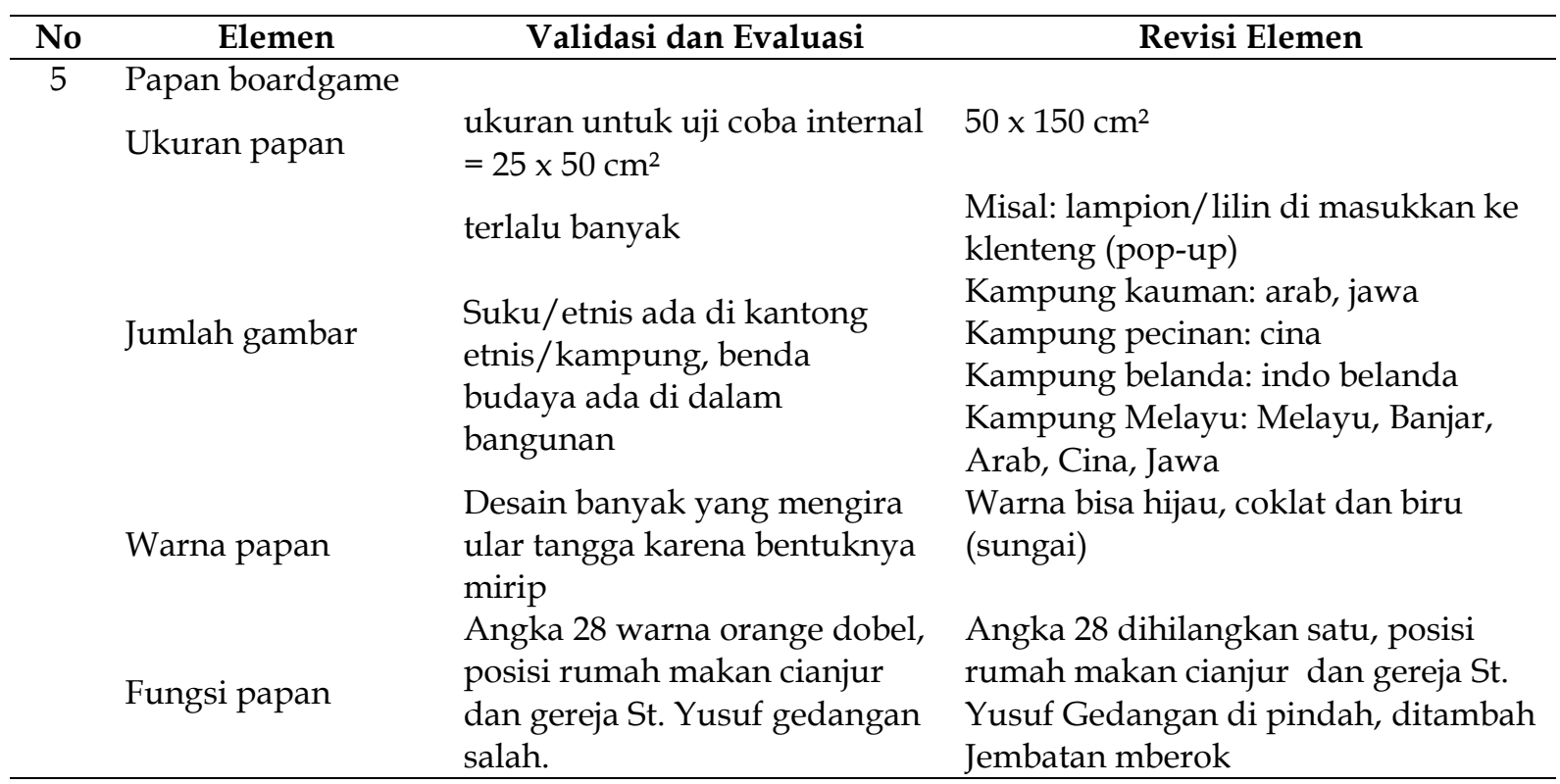

Tabel 2. Hasil Validasi Expert Judgement, Play test internal dan Peer Evaluation pada mekanik boardgame

\begin{tabular}{|c|c|c|c|}
\hline No & Mekanik & Evaluasi Mekanik & Revisi Mekanik \\
\hline \multirow[t]{2}{*}{1} & \multirow[t]{2}{*}{ Mekanik 1: Ruang } & \multirow[t]{2}{*}{$\begin{array}{l}\text { a. level 1,2,3 dan } 4 \\
\text { berhubungan, no } 28 \text { dobel } \\
\text { b. Sub ruang = membentuk } \\
\text { dari kepingan geometri, } \\
\text { ukuran sesuai, ada } 5 \text { kartu } \\
\text { yang harus revisi }\end{array}$} & $\begin{array}{l}\text { Desain di ubah lebih berhu- } \\
\text { bungan, nomer yang dobel di } \\
\text { hapus salah satu. } \\
5 \text { kartu bangunan (sub ruang) } \\
\text { di revisi }\end{array}$ \\
\hline & & & $\begin{array}{l}\text { iोin } \\
\text { int }\end{array}$ \\
\hline 2 & Mekanik 2: Waktu & $\begin{array}{l}\text { a. Waktu limit } 1 \text { menit ok } \\
\text { b. Penggunaan jam pasir } \\
\text { harus diingatkan } \\
\text { c. Durasi boardgame } 1 \\
\text { putaran kisaran } 30 \text { menit }\end{array}$ & $\begin{array}{l}\text { Jumlah jam pasir } 1 \text { menit } \\
\text { sebanyak } 2 \text { buah }\end{array}$ \\
\hline 3. & $\begin{array}{l}\text { Mekanik 3: } \\
\text { Obyek, Atribut dan Status }\end{array}$ & $\begin{array}{l}\text { Kartu-kartu masih perlu } \\
\text { diperbaiki. Kartu yang sering } \\
\text { muncul kartu bangunan } \\
\text { belanda }\end{array}$ & $\begin{array}{l}\text { Perbaikan kartu ada di } \\
\text { evaluasi elemen (kartu) }\end{array}$ \\
\hline 4 & $\begin{array}{l}\text { Mekanik 6: } \\
\text { Keterampilan }\end{array}$ & $\begin{array}{l}\text { Keterampilan mental: Memori } \\
\text { Pengamatan (ukuran terlalu } \\
\text { kecil). } \\
\text { Keterampilan Sosial: Menyi } \\
\text { kapi perbedaan suku/etnis } \\
\text { / budaya secara positif }\end{array}$ & Ukuran papan diperbesar \\
\hline 5 & $\begin{array}{l}\text { Mekanik 7: } \\
\text { Peluang }\end{array}$ & $\begin{array}{l}\text { Peluang jumlah segitiga, } \\
\text { suku/etnis, dan benda budaya } \\
\text { 5-6 sehingga dapat melangkah } \\
\text { 5-6 langkah }\end{array}$ & $\begin{array}{l}\text { Peluang di seimbangkan } \\
\text { s.d. } 6 \text { langkah }\end{array}$ \\
\hline 6 & $\begin{array}{l}\text { Keseimbangan } \\
\text { boardgame 1: } \\
\text { Keadilan }\end{array}$ & $\begin{array}{l}\text { jumlah angka sudah sama, } \\
\text { masih di temukan } 1 \text { yang } \\
\text { dobel (no } 28 \text { ) }\end{array}$ & Dihilangkan yang dobel \\
\hline 7 & $\begin{array}{l}\text { Keseimbangan } \\
\text { boardgame 2: } \\
\text { Tantangan Vs } \\
\text { keberhasilan }\end{array}$ & $\begin{array}{l}\text { Urutan tantangan suku/etnis } \\
\text { yang sama }>\text { benda budaya }> \\
\text { bangunan di Kota Lama. }\end{array}$ & $\begin{array}{l}\text { Ukuran suku/etnis diperbesar } \\
\text { agar seimbang antara } \\
\text { tantangan dan keberhasilan }\end{array}$ \\
\hline
\end{tabular}


Pengembangan Media Boardgame Multikultural AUD Ethnic Enclave Kota Lama melalui Desain Iteratif

DOI: 10.31004 /obsesi.v6i3.1904

\begin{tabular}{clll}
\hline No & \multicolumn{1}{c}{ Mekanik } & \multicolumn{1}{c}{ Evaluasi Mekanik } & \multicolumn{1}{c}{ Revisi Mekanik } \\
\hline 8 & $\begin{array}{l}\text { Keseimbangan board- } \\
\text { game 6: Kompetisi vs } \\
\text { kerjasama }\end{array}$ & Kompetisi ada & $\begin{array}{l}\text { Perlu ditambahkan mekanik } \\
\text { bekerjasama }\end{array}$ \\
9 & $\begin{array}{l}\text { Keseimbangan board- } \\
\text { game 7: Pendek vs }\end{array}$ & $\begin{array}{l}\text { Butuh waktu 30 menit } \\
\text { (sedang) } \\
\text { Panjang }\end{array}$ & $\begin{array}{l}\text { Panjang 30 langkah cukup } \\
\text { diselesaikan 30 menit }\end{array}$ \\
10 & $\begin{array}{l}\text { Keseimbangan } \\
\text { boardgame 8: Hadiah vs } \\
\text { hukuman }\end{array}$ & $\begin{array}{l}\text { belum ada hadiah, ada } \\
\text { hukuman dengan tidak } \\
\text { melangkah }\end{array}$ & Ditambahkan hadiah \\
11 & $\begin{array}{l}\text { Keseimbangan } \\
\text { boardgame 10: Simpel vs } \\
\text { kompleks }\end{array}$ & $\begin{array}{l}\text { Simpel, tetapi ada makna } \\
\text { yang kompleks }\end{array}$ & $\begin{array}{l}\text { Jumlah gambar disesuaikan } \\
\text { kebutuhan agar tidak terlihat } \\
\text { keseimbangan } \\
\text { boardgame 11: Detail vs } \\
\text { imajinasi }\end{array}$ \\
\hline
\end{tabular}

Berdasarkan hasil validasi expert judgement, play test internal dan Peer evaluation pada elemen dan mekanik "prototipe awal" dilakukan revisi elemen, pieces dan mekanik menjadi "prototipe revisi 1" boardgame multikultural ethnic enclave Kota Lama. Sebagaimana dapat dilihat pada gambar 8 .
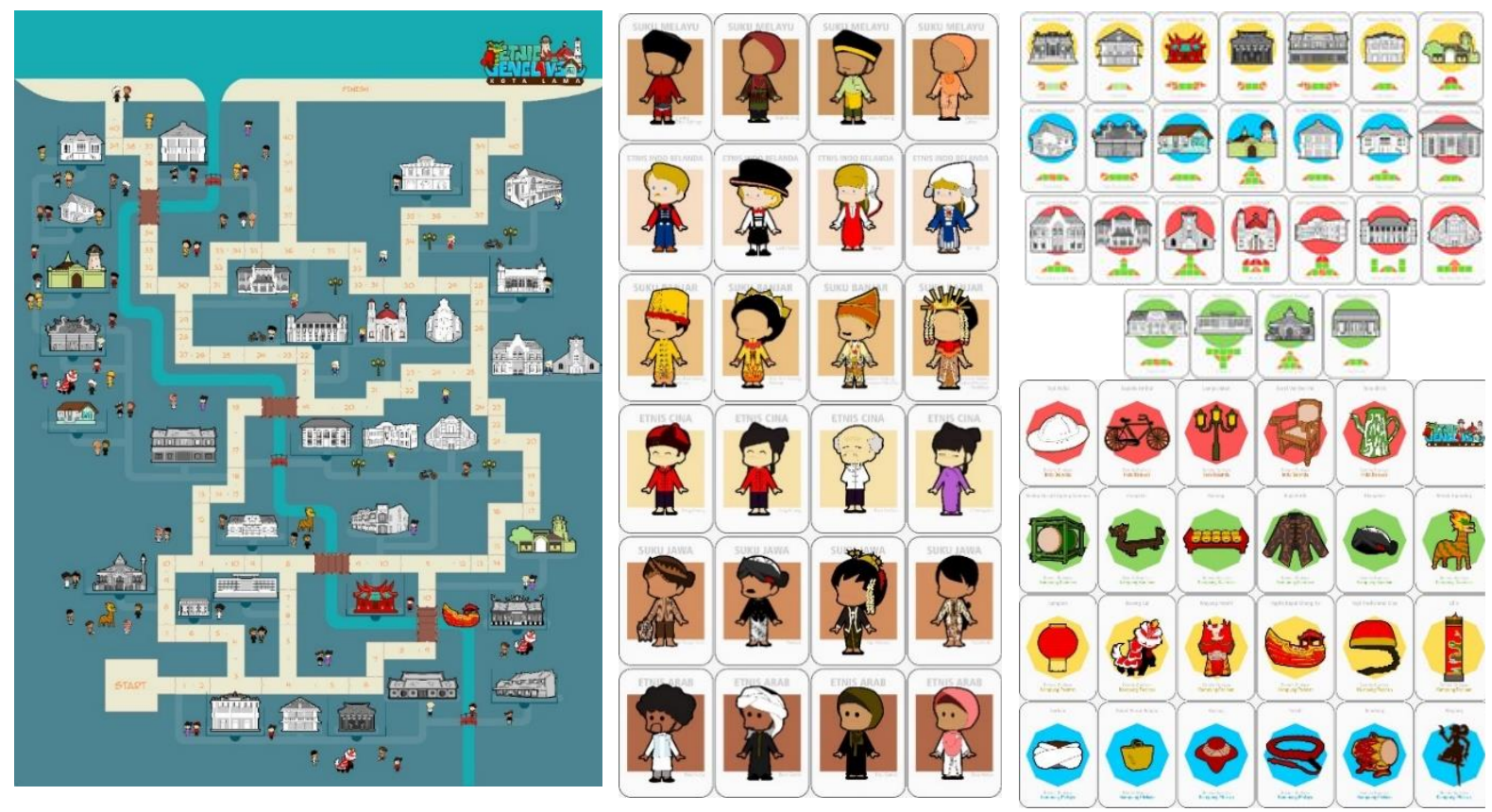

Gambar 8. Hasil CAD 2 berupa “prototipe revisi 1" Elemen Papan boardgame multicultural, kartu suku/etnis (24 kartu), kartu bangunan (25 kartu) dan kartu benda budaya (23 kartu)

Hasil CAD 2 tersebut berupa "prototipe revisi 1" boardgame multikultural ethnic enclave Kota Lama selanjutnya di Uji coba prototipe di TK Nasima Semarang dengan play test pada 2 orang anak TK Kelompok B (usia 5-6 tahun), dan Peer Evaluation oleh guru dan peneliti. Hasil play test dan Peer Evaluation selanjutnya di analisis serta menjadi bahan Focus Grup Discussion 2 (FGD 2) dan revisi "prototipe revisi 1" boardgame multikultural sebagai persiapan Uji Coba Kelompok kecil. Tabel 3 dan 4 adalah hasil rekapitulasi revisi yang merupakan bahan FGD 2 dan revisi "prototipe revisi 1" boardgame multikultural. 
Pengembangan Media Boardgame Multikultural AUD Ethnic Enclave Kota Lama melalui Desain Iteratif DOI: 10.31004/obsesi.v6i3.1904

Tabel 3. Hasil Play test dan Peer Evaluation elemen boardgame pada uji coba prototipe

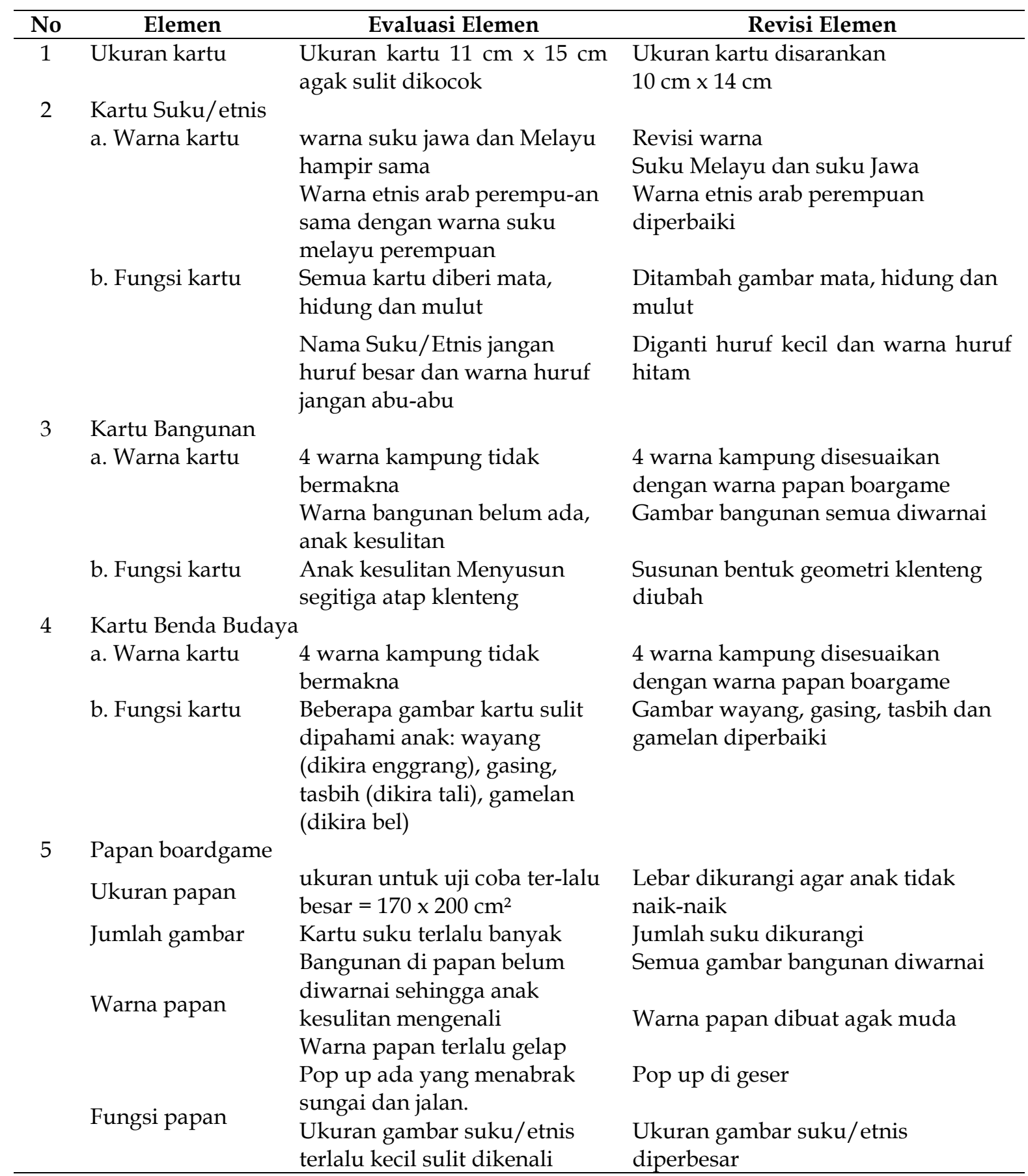

Tabel 4. Hasil Play test dan Peer Evaluation mekanik boardgame pada uji coba prototipe

\begin{tabular}{ccll}
\hline No & Mekanik & \multicolumn{1}{c}{ Evaluasi Mekanik } & \multicolumn{1}{c}{ Revisi Mekanik } \\
\hline 1 & Mekanik 1: Ruang & $\begin{array}{l}\text { Ukuran ruang tidak sama } \\
\text { sehingga anak salah hitung. }\end{array}$ & $\begin{array}{l}\text { Ukuran di samakan dan nomer } \\
\text { dihilangkan }\end{array}$ \\
& & Nomor membingungkan. \\
2 & Mekanik 2: Waktu & $\begin{array}{l}\text { Durasi 1 putaran kisaran 60 } \\
\text { menit lebih sehingga anak } \\
\text { menjadi tidak konsentrasi lagi. } \\
\text { Durasi 1 menit kartu } \\
\text { bangunan tidak cukup }\end{array}$ & $\begin{array}{l}\text { Jumlah Langkah 30 sebaiknya } \\
\text { dikurangi, rata-rata setiap anak }\end{array}$ \\
& & & \\
& &
\end{tabular}




\begin{tabular}{|c|c|c|c|}
\hline No & Mekanik & Evaluasi Mekanik & Revisi Mekanik \\
\hline 3. & $\begin{array}{l}\text { Mekanik 3: Obyek, } \\
\text { Atribut dan Status }\end{array}$ & Jumlah kartu terlalu banyak & Jumlah kartu dikurangi \\
\hline 4 & $\begin{array}{l}\text { Mekanik 7: } \\
\text { Peluang }\end{array}$ & Peluang melangkah kurang & $\begin{array}{l}\text { Peluang minimal dibuat } 3 \text {, Sisa } \\
\text { waktu } 1 \text { menit dipakai }\end{array}$ \\
\hline 5 & $\begin{array}{l}\text { Keseimbangan } \\
\text { boardgame 2: } \\
\text { Tantangan Vs } \\
\text { keberhasilan }\end{array}$ & $\begin{array}{l}\text { tantangan mencari bangun-an } \\
\text { agak sulit karena gam-bar } \\
\text { bangunan belum ber-warna, } \\
\text { anak kesulitan me-nyusun } \\
\text { bentuk segitiga }\end{array}$ & $\begin{array}{l}\text { Semua gambar bangunan } \\
\text { diwarnai } \\
\text { Menyusun bentuk segitiga } \\
\text { yang miring dihilangkan }\end{array}$ \\
\hline 6 & $\begin{array}{l}\text { Keseimbangan } \\
\text { boardgame 3: } \\
\text { Pilihan bermakna }\end{array}$ & $\begin{array}{l}\text { Pilihan jalan bisa ke kanan } \\
\text { atau ke kiri, pilihan kartu agar } \\
\text { anak tidak bosan }\end{array}$ & $\begin{array}{l}\text { Ukuran kartu diperkecil agar } \\
\text { mudah dikocok sehingga } \\
\text { pilihan variatif }\end{array}$ \\
\hline 7 & $\begin{array}{l}\text { Keseimbangan } \\
\text { boardgame 6: } \\
\text { Kompetisi vs } \\
\text { kerjasama }\end{array}$ & $\begin{array}{l}\text { kerjasama belum ada, } \\
\text { alternatif bekerjasama } \\
\text { menyusun bentuk geometri }\end{array}$ & $\begin{array}{l}\text { Ubah mekanik untuk } \\
\text { kerjasama }\end{array}$ \\
\hline 8 & $\begin{array}{l}\text { Keseimbangan } \\
\text { boardgame 7: } \\
\text { Pendek vs Panjang }\end{array}$ & $\begin{array}{l}\text { Waktu > } 30 \text { menit karena anak } \\
\text { baru pertama bermain } \\
\text { sehingga satu anak bosan } \\
\text { (laki-laki) satu anak masih } \\
\text { semangat (perempuan) }\end{array}$ & $\begin{array}{l}\text { Panjang boardgame dikurangi } \\
\text { atau peluang melangkah } \\
\text { ditambah }\end{array}$ \\
\hline 9 & $\begin{array}{l}\text { Keseimbangan } \\
\text { boardgame } 8: \\
\text { Hadiah vs } \\
\text { hukuman }\end{array}$ & $\begin{array}{l}\text { Hukuman tidak melangkah } \\
\text { ada, tetapi hadiah belum ada. }\end{array}$ & $\begin{array}{l}\text { Alternatif hadiah bisa diberi } \\
\text { gambar bangunan, isi jadi } \\
\text { hadiah melangkah }\end{array}$ \\
\hline 10 & $\begin{array}{l}\text { Keseimbangan } \\
\text { boardgame 9: } \\
\text { Kebebasan vs } \\
\text { kontrol }\end{array}$ & $\begin{array}{l}\text { Kebebasan memilih } \\
\text { permainan belum ada. }\end{array}$ & $\begin{array}{l}\text { Alternatif bermain bisa } \\
\text { divariasi dengan pilihan kartu } \\
\text { yang digunakan }\end{array}$ \\
\hline 11 & $\begin{array}{l}\text { Keseimbangan } \\
\text { boardgame 11: } \\
\text { Detail vs imajinasi }\end{array}$ & $\begin{array}{l}\text { Ada detail gambar tetapi } \\
\text { gambar imajinatif masih } \\
\text { kurang }\end{array}$ & $\begin{array}{l}\text { Ditambah desain gambar } \\
\text { imajinatif }\end{array}$ \\
\hline
\end{tabular}

Berdasarkan hasil play test dan Peer evaluation pada elemen dan mekanik "prototipe revisi 1" di uji coba prototipe maka dilakukan revisi elemen, pieces dan mekanik menjadi "prototipe revisi 2" boardgame multikultural ethnic enclave Kota Lama. Selengkapnya lihat gambar 9 .

Tabel 5. Hasil Play test dan Peer Evaluation elemen boardgame pada uji coba kelompok kecil

\begin{tabular}{|c|c|c|c|}
\hline No & Elemen & Evaluasi Elemen & Revisi Elemen \\
\hline \multirow[t]{4}{*}{1} & Kartu Suku/etnis & & \\
\hline & Warna kartu & warna suku jawa dan Melayu & Revisi warna \\
\hline & & hampir sama & Suku Melayu dan suku Jawa \\
\hline & & $\begin{array}{l}\text { Warna etnis arab perempu-an } \\
\text { sama dengan warna suku } \\
\text { melayu perempuan }\end{array}$ & $\begin{array}{l}\text { Warna etnis arab perempuan } \\
\text { diperbaiki }\end{array}$ \\
\hline \multirow[t]{2}{*}{2} & Kartu Bangunan d & benda budaya & \\
\hline & Warna kartu & $\begin{array}{l}\text { warna kampung di kartu ti- } \\
\text { dak sama dengan di papan }\end{array}$ & $\begin{array}{l}4 \text { warna kampung disesuaikan } \\
\text { dengan warna papan boargame }\end{array}$ \\
\hline \multirow[t]{3}{*}{3} & Papan boardgame & & \\
\hline & Ukuran papan & $\begin{array}{l}\text { Ukuran }=90 \times 200 \mathrm{~cm}^{2} \text {, masih } \\
\text { terlalu lebar }\end{array}$ & $\begin{array}{l}\text { Lebar dikurangi agar anak tidak } \\
\text { naik-naik }\end{array}$ \\
\hline & Warna papan & $\begin{array}{l}\text { Warna papan tidak sesuai } \\
\text { dengan kode warna di kartu }\end{array}$ & $\begin{array}{l}\text { Warna kode kampung di papan } \\
\text { disesuaikan dengan kartu }\end{array}$ \\
\hline
\end{tabular}


Hasil CAD 3 tersebut berupa "prototipe revisi 2" boardgame multikultural ethnic enclave Kota Lama selanjutnya di Uji coba kelompok kecil di TK Nasima Semarang dengan play test pada 8 orang anak TK Kelompok B (usia 5-6 tahun), dan Peer Evaluation oleh guru dan peneliti. Hasil play test dan Peer Evaluation selanjutnya di analisis serta menjadi bahan Focus Grup Discussion 3 (FGD 3) dengan expert judgement boardgame dari Studio Kumara Bandung dan revisi "prototipe revisi 2 " boardgame multikultural. Tabel 5 dan 6 adalah hasil rekapitulasi revisi yang merupakan bahan FGD 3 dan revisi "prototipe revisi 2" boardgame multikultural.

Tabel 6. Hasil Play test dan Peer Evaluation mekanik boardgame pada uji coba kelompok kecil

\begin{tabular}{|c|c|c|c|}
\hline No & Mekanik & Evaluasi Mekanik & Revisi Mekanik \\
\hline 1 & Mekanik 1: Ruang & Jumlah ruang dikurangi & $\begin{array}{l}\text { Jumlah ruang sebaiknya } \\
\text { kisaran } 30\end{array}$ \\
\hline 2 & $\begin{array}{l}\text { Mekanik 7: } \\
\text { Peluang }\end{array}$ & Peluang melangkah kurang & $\begin{array}{l}\text { Peluang minimal dibuat } 3 \text {, } \\
\text { peluang memanfaatkan sisa } \\
\text { waktu } 1 \text { menit boleh }\end{array}$ \\
\hline 3 & $\begin{array}{l}\text { Keseimbangan board- } \\
\text { game 2: tantangan Vs } \\
\text { keberhasilan }\end{array}$ & $\begin{array}{l}\text { tantangan jalan panjang ( } 42 \\
\text { langkah) keberhasilan } \\
\text { mencapai finish } 50 \%\end{array}$ & $\begin{array}{l}\text { Panjang jalan kisaran } 30 \\
\text { langkah }\end{array}$ \\
\hline 4 & $\begin{array}{l}\text { Keseimbangan } \\
\text { boardgame 7: Pendek vs } \\
\text { Panjang }\end{array}$ & $\begin{array}{l}\text { Anak yang berhasil mencapai } \\
\text { finish hanya } 25 \%\end{array}$ & $\begin{array}{l}\text { Panjang boardgame diku- } \\
\text { rangi, peluang melangkah } \\
\text { ditambah }\end{array}$ \\
\hline 5 & $\begin{array}{l}\text { Keseimbangan } \\
\text { boardgame 8: Hadiah vs } \\
\text { hukuman }\end{array}$ & $\begin{array}{l}\text { Hukuman tidak melangkah } \\
\text { ada, tetapi hadiah belum ada. }\end{array}$ & $\begin{array}{l}\text { Alternatif hadiah bisa diberi } \\
\text { gambar bangunan, lihat jumlah } \\
\text { isi bangunan sebagai hadiah } \\
\text { melangkah }\end{array}$ \\
\hline 6 & $\begin{array}{l}\text { Keseimbangan } \\
\text { boardgame 11: Detail vs } \\
\text { imajinasi }\end{array}$ & $\begin{array}{l}\text { Ada detail gambar tetapi } \\
\text { gambar imajinatif masih } \\
\text { kurang }\end{array}$ & $\begin{array}{l}\text { Ditambah desain gambar } \\
\text { imajinatif }\end{array}$ \\
\hline
\end{tabular}
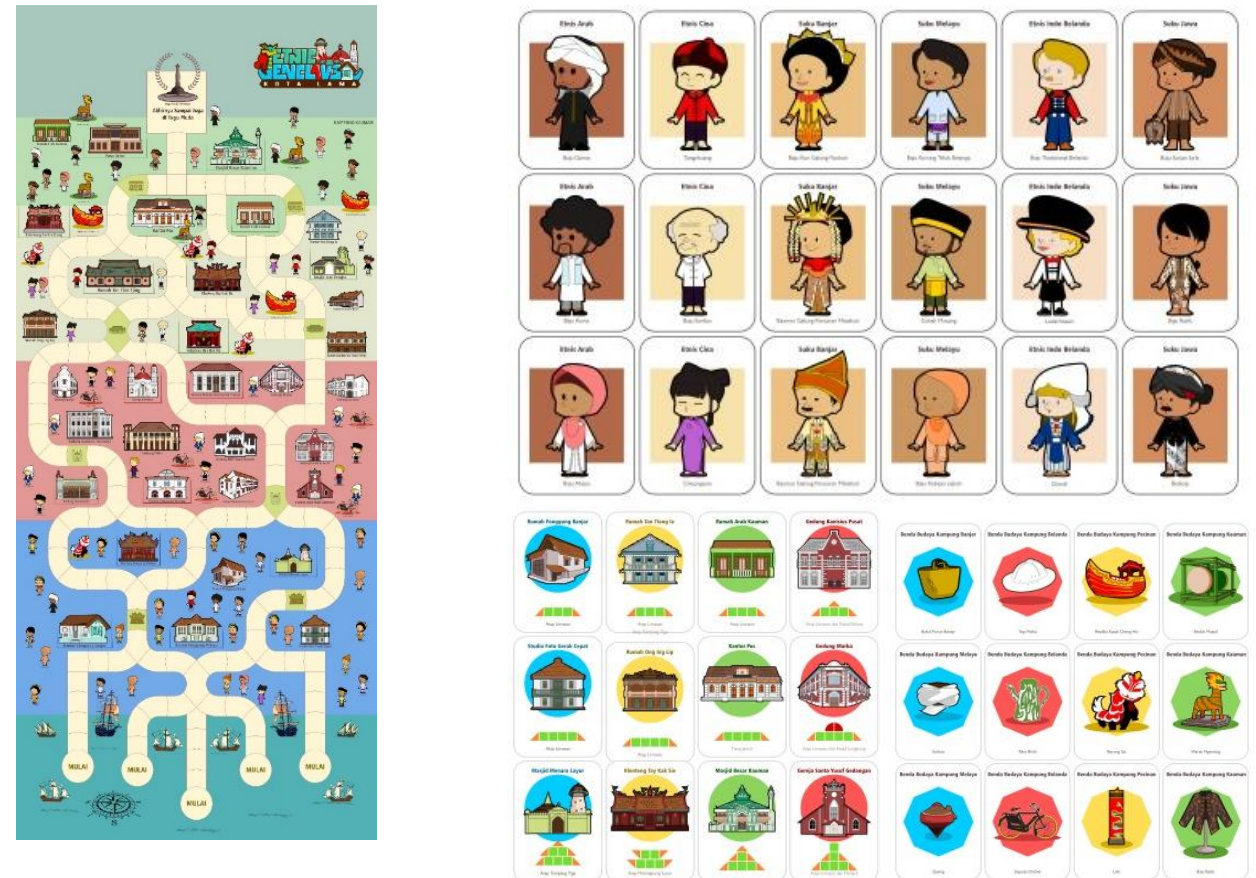

Gambar 9. Hasil CAD 3 berupa "prototipe revisi 2" Elemen Papan boardgame multikultural, kartu suku/etnis (18 kartu), kartu bangunan (12 kartu) dan kartu benda budaya (12 kartu) 
Berdasarkan evaluasi elemen dan mekanik, ada beberapa hal yang dibahas pada FGD 3 dengan expert judgement dari Studio Kumara Bandung diantaranya tentang panjang boardgame yang ideal untuk anak usia 5 s.d. 6 tahun. Play test "prototipe revisi 1" panjang 40 langkah rata-rata capaian hanya 29 langkah belum ada yang sampai finish dan ada anak sudah bosan sebelum smpai finish. Sedangkan playtest "prototipe revisi 2" panjang 45 langkah ratarata capaian 31 langkah dan ada 25\% anak mencapai finish. Strategi yang diusulkan oleh expert judgement bisa dengan mengurangi panjang ruang (space) menjadi 30 langkah. Hal ini sesuai dengan keseimbangan boardgame pendek versus panjang dimana anak akan bosan apabila terlalu panjang (Schell, 2015). Boardgame bisa juga dibuat kontinu bukan linear, kalau kontinu batasannya waktu (time base) sedangkan linear batasannya sampai finish. Selain itu anak sekarang sudah memiliki referensi game yang biasa dimainkan sehingga anak bisa saja bosan Ketika memainkan game edukasi yang tidak sejenis dengan yang biasa dimainkan anak.

Berikutnya pada saat anak mencari suku/etnis di papan boardgame yang memiliki ciri-ciri yang sama (warna dan bentuk pakaian) dengan kartu suku/etnis lebih mudah bagi anak. Peluang untuk mencari warna suku/etnis yang sama meski bentuk pakaian berbeda di berikan tetapi hanya anak tertentu yang paham, karena sebenarnya ini salah satu tujuannya anak menyadari keberagaman dari warna suku/etnis meski berbeda pakaian dan berbeda gender. Tujuannya agar anak belajar menghargai aspek perbedaan suku/etnis (Mahfud, 2013). Kendala lain anak masih mencari-cari terus suku/etnis dengan warna dan ciri-ciri yang sama padahal sudah tidak ada lagi. Saran yang diusulkan expert judgement ada 2 alternatif yaitu dengan menuliskan jumlahnya di kartu suku/etnis atau jumlah gambar di kartu sama dengan jumlah gambar di papan boardgame.

Bahasan berikutnya anak Ketika mencari benda budaya belum bisa membedakan benda tersebut di dalam bangunan atau di luar bangunan. Akibatnya anak mencari-cari di dalam bangunan padahal sebenarnya benda budaya ada di luar bangunan. Ada alternatif kartu benda budaya dihilangkan dan dijadikan peluag untuk hadiah yang dapat ditemukan di jalan yang ada di papan boardgame. Saran dari expert judgement hadiah atau reward dapat diberikan di luar permainan boardgame. Selain itu ada beberapa alternatif dari expert judgement, anak diberi kesempatan menggunakan satu kartu dulu misal kartu suku/etnis kemudian bisa memilih menggunakan satu kartu bangunan lalu baru menggunakan gabungan 2 kartu misal kartu suku/etnis dan kartu bangunan. Hal ini sesuai dengan keseimbangan boardgame yaitu pilihan yang bermakna (Meaningfull Choice) sehingga anak bisa fokus meningkatkan keterampilan tertentu (Schell, 2015).

Kesadaran tentang keberagaman (diversity awareness) yang ditemukan saat play test di uji coba prototipe diantaranya adalah anak dapat mengidentifikasi etnis arab yang berjenggot dan identifikasi benda budaya lebih mudah dibandingkan bangunan seperti: congklak, baju batik, teko blirik, dan barongsai. Sedangkan pada saat play test di uji coba kelompok kecil, anak mulai dapat mengidentifikasi nama suku seperti suku Jawa, etnis Cina, dan etnis Arab. Anak juga dapat mengidentifikasi ciri-ciri suku/etnis seperti jenggot dan kulit putih. Anak dapat mengidentifikasi benda budaya lebih mudah dibandingkan bangunan seperti: congklak, baju batik, teko blirik, warak, bedug dan barongsai.

State of the art atau penelitian terdahulu yang relevan diantaranya "Pengembangan Media Permainan MONAYA untuk Meningkatkan Pemahaman Multikultural pada Anak Usia 7-8 tahun" bertujuan untuk meningkatkan pemahaman multikultural anak usia 7- 8 tahun melalui media permainan MONAYA (Monopoli Budaya). Temuan penelitiannya antusias anak yang sangat tinggi sehingga layak digunakan (Indah Firdausi, Hapidin, \& Tarwiyah, 2018). Research gap dari penelitian tersebut lebih difokuskan pada pengetahuan saja tetapi mengabaikan keterampilan dan sikap toleransi. Pondasi sikap toleransi berupa kesadaran (awareness) tentang keberagaman pada usia 5 tahun, berupa kesadaran tentang keberagaman dengan mengkomunikasikan dan menyikapi keberagaman secara positif melalui board game multikultural. 
Penelitian tentang "Designing a board game as a vehicle for multicultural education", merupakan penelitian berupa desain Board Game Myth untuk anak muda tentang identitas budaya dan proses konstruksi Identitas orang Finlandia. Content Permainan berupa seni nasional Finlandia yang disebut "pure finnishness" / Nasionalisme orang Finlandia (Lassi A. Liikkanen, 2010). Research gap dari penelitian Board game Myth adalah membuktikan bahwa board game dapat mengkonstruksi identitas bangsa yang multikultural pada anak muda. Sedangkan peneliti mengembangkan board game multikultural untuk anak usia dini yang masih di tahap kesadaran tentang keberagaman.

Boardgame multikultural Ethnic Enclave Kota Lama dapat menjadi media pembelajaran untuk meningkatkan kesadaran tentang keberagaman yang merupakan pondasi dari sikap toleransi. Boardgame ini menjadi produk inovasi media pembelajaran multikultural bagi guru PAUD, orangtua, Lembaga PAUD dan penerbit. (implikasi kePAUDan belum terlihat jelas dan juga dukungan riset yang relevannya)

\section{SIMPULAN}

Boardgame tematik didesain melalui identifikasi ide "prototipe awal" untuk elemen, jumlah dan mekanik;Boardgame multikultural dirancang melalui desain iterative: (a) Validasi expert judgement, play test internal dan peer evaluation pada "prototipe awal" menjadi "prototipe revisi 1", (b) play test saat uji coba prototipe 2 anak dan peer evaluation "prototipe revisi 1" menjadi "prototipe revisi 2", (c) play test saat uji coba kelompok kecil 8 anak, peer evaluation dan expert judgement boardgame "prototipe revisi 2" menjadi "prototipe revisi 3". Boardgame dapat efektif digunakan untuk menumbuhkan kemampuan anak dalam mengidentifikasikan kesadaran tentang keberagaman seperti identifikasi nama dan ciri-ciri suku/etnis, serta budaya.

\section{UCAPAN TERIMAKASIH}

Tim peneliti berterima kasih atas Hibah penelitian dari Simlitabmas melalui skema Penelitian Terapan Unggulan Perguruan Tinggi (PTUTP), sehingga dapat mengembangkan media boardgame multikultural.

\section{DAFTAR PUSTAKA}

Akmal, H. A., \& Coulton, P. (2019). Research Through Board Game Design. Proceedings of RTD 2019, (March). https:/ / doi.org/10.6084/m9.figshare.7855808.v1

Banks, J. A. C. A. M. G. B. (2015). Multicultural Education: Issues and Perspectives, 9th Edition 9th Edition, Kindle Edition. In New Jersey: John Wiley and Sons.

Chatfield, T. (2011). Fun Inc.: Why Games Are the 21st Century's Most Serious Business (Internatio). Retrieved from http://www.mindnote.nl/tag/tom-chatfield/

Chiong, M. C., Artawan, C. A., Wahyudi, A. T., Studi, P., Komunikasi, D., Seni, F., ... Siwalankerto, J. (2018). Perancangan Board Game Pembelajaran Bagi Perkembangan Karakter Anak Usia 4-6 Tahun. Jurnal DKV Adiwarna, 1(12), 1-9. Retrieved from http://publication.petra.ac.id/index.php/dkv/article/view/7368/6682

Hendro, E. P. (2015). Pelestarian Kawasan Konservasi di Kota Semarang. Jurnal Konservasi $\begin{array}{lll}\text { Cagar } \quad \text { Budaya, } & \text { 9(1), }\end{array}$ https://doi.org/10.33374/jurnalkonservasicagarbudaya.v9i1.159

Hunsucker, A. J. (2016). Board Games as a Platform For Collaborative Learning. Meaningful Play 2016 Conference, (October), 1-31. Retrieved from https:// www.researchgate.net/ publication/309385174

Kosa, M., \& Yilmaz, M. (2017). The Design Process of a Board Game for Exploring the Territories of the United States. Press Start, 4(1), 36-52. Retrieved from http://pressstart.gla.ac.uk/index.php/press-start/article/view/67 
Lassi A. Liikkanen. (2010). Designing a board game as a vehicle for multicultural education. 2010. Retrieved from https://1.kryptoniitti.com/lassial/files/publications/100609Designing board_game.pdf

Livikacansera, S. (2012). Permainan Tertua di Dunia Ternyata Bagian dari Peradaban Islam. Mahfud. (2013). Pendidikan Multikultural. Yogyakarta: Pustaka Pelajar.

Mubah, A. S. (2011). Revitalisasi Identitas Kultural Indonesia di Tengah Upaya Homogenisasi Global. Jurnal Global Dan Strategis, Vol 5(No 3), 251-260. https://doi.org/10.1108/ 20466091211287128

Murtiningsih, S. (2012). Pendidikan Multikultural melalui Dolanan Anak: Studi tentang Dolanan Anak "Sundamanda." 12-13.

Nahak, H. M. . (2019). Upaya Melestarikan Budaya Indonesia Di Era Globalisasi. Jurnal Sosiologi Nusantara, 5(1), 65-76. https://doi.org/10.33369/jsn.5.1.65-76

Rajkovic, A. I., Ruzic, M. S., \& Ljujic, B. (2019). Board Games as Educational Media: Creating and Playing Board Games for Acquiring Knowledge of History. Iartem E-Journal, 11(2), 27-29. https://doi.org/10.21344/iartem.v11i2.582

Ramani, G. B., Siegler, R. S., \& Hitti, A. (2012). Taking it to the classroom: Number board games as a small group learning activity. Journal of Educational Psychology, 104(3), 661-672. https://doi.org/10.1037/a0028995

Risa Nur Sa'adah. (2020). Metode Penelitian R\&D (Research and Development) Kajian Teoritis dan Aplikatif. In Literasi Nusantara (Vol. 1). Literasi Nusantara.

Schell, J. (2015). The Art of Game design: A Book of Lenses (Second). New York: CRC Press Taylor \& Francis Group.

Siregar, S. M., \& Nadiroh, N. (2017). Peran Keluarga Dalam Menerapkan Nilai Budaya Suku Sasak Dalam Memelihara Lingkungan. Jurnal Green Growth Dan Manajemen Lingkungan, 5(2), 28. https://doi.org/10.21009/jgg.052.04

Soekmono, R. (2017). Program Bahasa Holistik ( Penelitian Pengembangan di Kelompok B Taman Kanak-Kanak Nasima Semarang). Jurnal Pendidikan Anak Usia Dini, 11(2), 308-322. https://doi.org/10.21009/JPUD.112.09

Treher, E. N. (2010). Learning with Board Games Tools for Learning and Retention Learning with Board Games.

Usman, A. (2018). Pendidikan Berparadigma Multikultural. Media Indonesia.

Utari. (2017). Meningkatkan Sikap Semangat Nasionalisme Kepada Anak-anak Usia Dini Dengan Mengajarkan Permainan Tradisional di Era Globalisasi. Retrieved from http://semnastafis.unimed.ac.id/wp-content/uploads/2017/11/10.-Utari-ok-PakRidho-namanya-apa-hanya-Utari...pdf

Yoga Agustin, D. S. (2011). Penurunan Rasa Cinta Budaya Dan Nasionalisme Generasi Muda Akibat Globalisasi. Jurnal Sosial Humaniora, 4(2), 177-185. https:/ / doi.org/10.12962/ j24433527.v4i2.632 https:// doi.org/10.12962/j24433527.v4i2.632 